\title{
Facial Nerve Neuropathy Caused by its Stretching
}

\author{
Oleksii 0. Tymofieiev ${ }^{1, *}$, Anna I. Kryvosheieva², Beka Beridze ${ }^{3}$ \\ ${ }^{1}$ Chair of the Department of Maxillofacial Surgery, Stomatology Institute, Shupyk NMAPE, Kyiv, Ukraine (Prof, ScD) \\ 2 Department of Oral and Maxillofacial Surgery, PHEE "Kyiv Medical University", Kyiv, Ukraine (Assis Prof, PhD) \\ ${ }^{3}$ Department of Maxillofacial Surgery, Stomatology Institute, Shupyk NMAPE, Kyiv, Ukraine (PhD Student)
}

\author{
ABOUT ARTICLE \\ Article history: \\ Paper received 10 April 2017 \\ Accepted 15 April 2017 \\ Available online 30 June 2017 \\ Keywords: \\ Facial nerve \\ Electrophysiological indices \\ Nerve stretching \\ Parotid gland \\ Submandibular gland \\ Facial nerve paralysis \\ Facial nerve neuropathy
}

\begin{abstract}
A B S T R A C T
Purpose.

Study the dynamics of changes in electrophysiological parameters of the facial nerve in cases after operative interventions on the parotid and submandibular glands, as well as determine the possibility of using electrical stimulation of the nerve on the hardware-software complex "DIN-1" for the treatment of neuropathy caused by its stretching.

Patients and Methods.

31 patients were examined after surgery on the parotid and submandibular glands.

Results.

Based on the performed patient examinations after parotidectomy and extirpation of the submandibular glands, it was established that in the postoperative period they may have neuropathy of the facial nerve, the cause of which is the stretching of the nerve. Clinical improvement and elimination of symptoms were correlated with normalization of electrophysiological indices of the state of affected branches of the facial nerve.

Conclusions.

Due to the use of the hardware-software complex "DIN-1" for diagnosis and treatment of the facial nerve neuropathy caused by its stretching, we managed not only to identify and prove the existence of this disease, but also to shorten the terms of rehabilitation of patients 4 times.

(C) Diagnostics and Treatment of Oral and Maxillofacial Pathology. Published by OMF Publishing, LLC. All rights reserved.
\end{abstract}

\section{Introduction}

In recent years, according to our clinic, the number of patients with tumors and tumor-like formations of parotid salivary glands has increased [1-3]. The most common complication after performing such a complex surgical intervention as parotidectomy is paralysis of the facial nerve or its individual branches.

Often, tumors or tumor-like formations of the parotid gland are under the branches or trunk of the facial nerve. The branches of the facial nerve, being under the tumor, are already in the "stretched state". In order to separate the facial nerve or its branches from a tumor or tumor-like formation, it is necessary to "isolate" the branches of the nerve while slightly stretching them. In this way, we can remove the pathological focus with minimal trauma to the facial nerve (Fig 1). In the postoperative period, these patients develop neuropathy of the facial nerve or its branches.

The purpose of the study was to investigate the dynamics of changes in the electrophysiological indices of the "stretched" facial nerve in patients with tumors and tumor-

${ }^{*}$ Corresponding author. Department of Maxillofacial Surgery, Stomatology Institute, Shupyk NMAPE, 4-a Pidvysotskogo Street, Kyiv 01103, Ukraine.

Tel., fax: +38 (044) 5283517.

E-mail address: tymofeev@gmail.com (O.O. Tymofieiev)

Instagram: @oleksii.tymofieiev like formations of the parotid glands and submandibular glands after surgical interventions and to determine the possibility of using electrical stimulation of the nerve at the hardware-software complex "DIN-1" in the rehabilitation period for treatment of neuropathy.

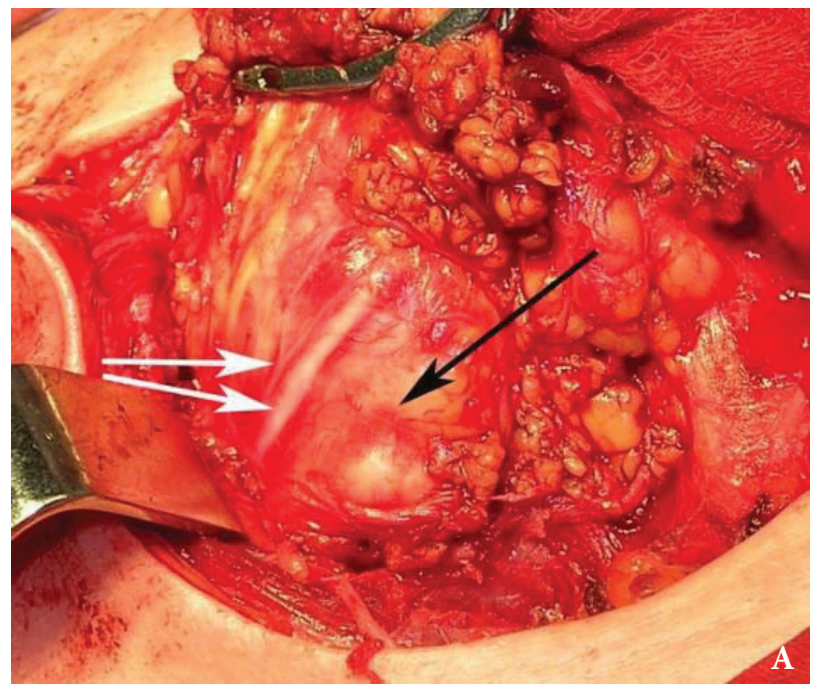

FIGURE 1. Intraoperative view (A) of the parotid gland tumor (black arrow) located under the branches of the facial nerve (white arrows) (Fig 1 continued on the next page.) 


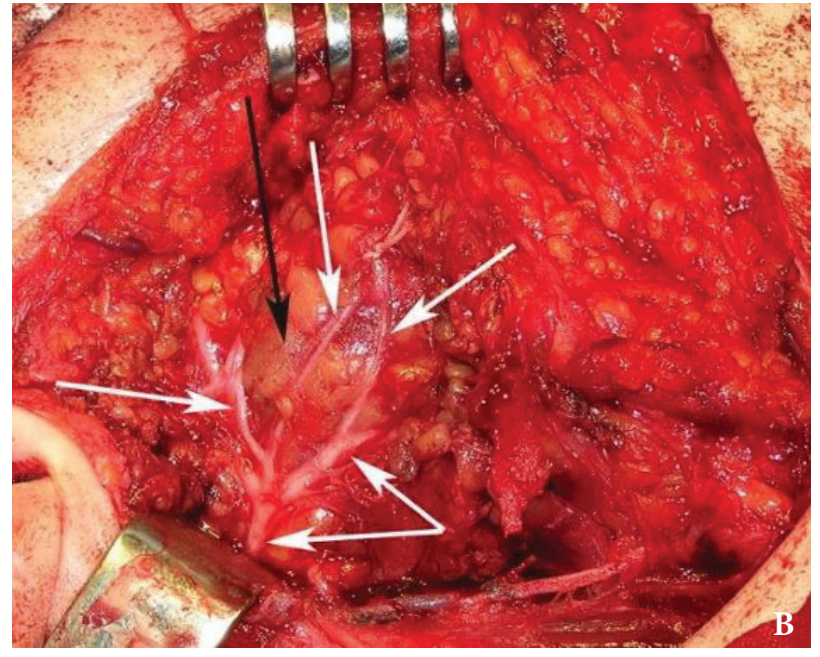

FIGURE 1 (cont'd). Intraoperative view (B) of the parotid gland tumor (black arrow) located under the branches of the facial nerve (white arrows).

\section{Patients and Methods}

Under our supervision, there were 31 patients aged 18 to 60 years who underwent operations on the parotid gland - parotidectomy and submandibular gland - extirpation of the gland. The operations were carried out for the removal of benign tumors and tumor-like formations of major salivary glands. In all these examined cases tumors or tumor-like formations were under the branches or trunk of the facial nerve. Therefore, when carrying out parotidectomies, we had not to break the integrity of the nerve, stretch its branches, separate and move them away from tumor formation. At the same time, the integrity of the nerve trunk was preserved and, in our opinion, the operations were performed with minimal trauma to the facial nerve. However, the next day after such operations, neuritis (neuropathy) of certain branches of the facial nerve was diagnosed; i.e. the patient had a paralysis of his facial muscles. In surgical interventions (removal of tumors) on the parotid glands, any branch (depending on the localization of the pathological focus) of the facial nerve was involved in the pathological process (stretching), and when removing the submandibular glands, only the marginal branch of this motor nerve was involved.

The depth of paralysis of facial muscles was determined according to the most accessible and universal, in our opinion, six-degree system (scale) according to House W.F., Brackmann D.E. (1985) [4]. Some authors (Kang TS, et al., 2002; Vrabec JT, et al., 2009) [5-7] proposed to make some changes into the House and Brackmann six-degree system. But initially a six-degree scale for the determination of facial paralysis by House-Brackmann (1985) is next:

Normal (1 degree) - the symmetry of the face corresponds to the morphophysiological features of the individual. There are no deviations in the functions of facial muscles during rest or arbitrary movements, pathological involuntary movements are excluded.
Slight paralysis (2 degree) - during rest symmetrical face. Arbitrary movements: the skin of the forehead is folded; Moderate effort when closing eyes; Asymmetry of the mouth during a conversation.

Moderate paralysis (3 degree) - during rest there is a slight asymmetry of the face. Arbitrary movements: forehead skin - moderate; Eyes completely close with difficulty; when the angle of the mouth moves, there is a slight weakness, movement is made with effort.

Moderately severe paralysis (4 degree) - during rest there is an asymmetry of the face, as well as reduced muscle tone. Arbitrary movements: the forehead's skin is motionless; Eyes cannot be completely closed; there is an asymmetry when moving corner of the mouth, the movement of the muscles is difficult.

Severe paralysis (5 degree) - during rest there is a considerable degree of asymmetry of the face. Arbitrary movements: the forehead's skin is motionless; Eyes do not close completely, when closed, the pupil rises; Mouth asymmetric, motionless.

Total paralysis ( 6 degree) - the patient's face is still, a masklike face (usually one half). Arbitrary movements of the skin of the forehead, mouth, eyes are absent.

To measure the static and dynamic electrophysiological parameters (conduction, resistance, tone) of soft tissue sites that are innervated by the facial nerve, 31 subjects were equipped with a hardware-software complex for diagnosis and treatment (with simultaneous electrical stimulation of the nerve) "DIN-1" [8, 9]. For the treatment of this neuropathy, we conducted two courses of electrostimulation of the nerve (one course of electrostimulation lasted for 7 days) with a break of also 7 days, i.e. rehabilitation treatment lasted 21-22 days.

The control of the electrophysiological parameters of the facial nerve (conduction, resistance and tone) was 32 subjects - practically healthy people of the same age, without concomitant diseases. The control group of the duration of the treatment of postoperative neuropathies was 36 patients after operations on the parotid and submandibular glands (if there was a stretching of the facial nerve during the operation). This control group in the postoperative period used traditional medicaments (Nucleo CMP forte (Grupo Ferrer Internacional, S.A., Spain) and Neurovitan (Hikma Pharmaceuticals PLC, Jordan)), i.e. rehabilitation treatment for these patients was carried out without the use of the hardware-software complex "DIN-1".

The obtained digital survey data was processed by a conventional variational-statistical method using a personal computer and statistical software package "SPSS 11.0 for Windows" and "Microsoft Excel 2000". Reliability of the survey results was assessed by Student criteria. Differences were considered significant at $\mathrm{P}<0.05$.

\section{Results}

A study of the depth of the paralysis of facial muscles with neuropathies caused by the stretching of the facial nerve 
(with electrical stimulation on the hardware-software complex "DIN-1") showed that the next day after the operation, the moderately severe paralysis (4 degree) was detected in 18 of 31 patients (in 58.0\%), moderate paresis (3 degree) was observed in 10 subjects (32.3\%), slight paralysis ( 2 degree) - in 3 patients $(9.7 \%)$. On the 3 rd day after parotidectomy: the moderately severe paralysis (4 degree) was detected in 18 of 31 patients $(58.0 \%)$, moderate paralysis (3 degree) was observed in 10 subjects $(32.3 \%)$, slight paralysis (2 degree) -3 people $(9.7 \%)$. On the 7 th day after the operation: the average paralysis (4 degree) was detected in 15 of 31 patients (in $48.4 \%$ ), moderate paresis ( 3 degree) was observed in 9 subjects (29.0\%), minor paralysis ( 2 degree) - in 7 people (22.6\%). On the 14 th day after the surgical intervention: the moderately severe paralysis (4 degree) was detected in 3 of 31 patients $(9.7 \%)$, moderate paralysis (3 degree) was observed in 13 subjects (41.9\%), slight paralysis ( 2 degree) - in 15 people $(48.4 \%)$. On the 21-22 day after parotidectomy: a slight paralysis (2 degree) was observed in 4 subjects (12.9\%), and the norm (1 degree) was observed in 27 patients $(87.1 \%)$.

A study of the depth of the paralysis of facial musculature with neuropathies caused by nerve stretching in 36 patients of the control group (without treatment with the hardware-software complex «DIN-1») showed that on the next day after the operation, the moderately severe paresis (4 degree) was detected in 22 of 36 patients $(61.1 \%)$, moderate paralysis (3 degree) were observed in 10 subjects $(27.8 \%)$, slight paralysis (2 degree) - in 4 patients $(11.1 \%)$. On the 7 th and 14 th days after parotidectomy: the moderately severe paralysis (4 degree) was detected in 22 of 36 patients $(61.1 \%)$, moderate paralysis (3 degree) was observed in 10 subjects (27.8\%), slight paralysis (2 degree) - 4 people (11.1\%). On the $21-22$ th day after the operation: the moderately severe paralysis (4 degree) was detected in 15 of 36 patients (41.7\%), moderate paralysis (3 degree) was observed in 9 subjects (25.0\%), slight paralysis (2 degree) - in 12 people $(33.3 \%)$. One (1) month after the operation: middle paresis (4 degree) was detected in 6 of 36 patients (16.7\%), moderate paralysis (3 degree) was observed in 18 subjects $(50.0 \%)$, slight paralysis (2 degree) - in 12 people (33.3\%). Three (3) months after the operation, a slight paralysis (2 degree) was observed in 5 subjects (13.9\%), and a norm (1 degree) in 31 patients $(86.1 \%)$.

On the next day after the surgery (Fig 2), the average arithmetic index of conduction of the marginal branch of the facial nerve was $31.5 \pm 1.1$ (at the norm of 97.4 \pm 2.0 conventional units). This indicates a significant $(\mathrm{P}<0.001)$ decrease of this indicator. On the $3 \mathrm{rd}$ day after parotidectomy, a significant decrease of this indicator continued to $40.4 \pm 1.1(\mathrm{P}<0.001)$. On the 7 th day after the operation, the conductivity index of the marginal branch slightly increased and amounted to $45.8 \pm 1.0$ units, i.e. remained significantly lower ( $P$ $<0.001)$ compared to healthy people. On the 14 th day of the treatment, the conductivity index of the marginal branch continued to increase and was $81.3 \pm 1.4$ units, but remained significantly lower $(\mathrm{P}<0.001)$ compared to healthy people. At 21-22 days, the conductivity index of the peripheral branch of the facial nerve for these subjects was $93.8 \pm 1.2$ units and reliably $(\mathrm{P}>0.05) \mathrm{did}$ not differ from the group of healthy people (Fig 2).

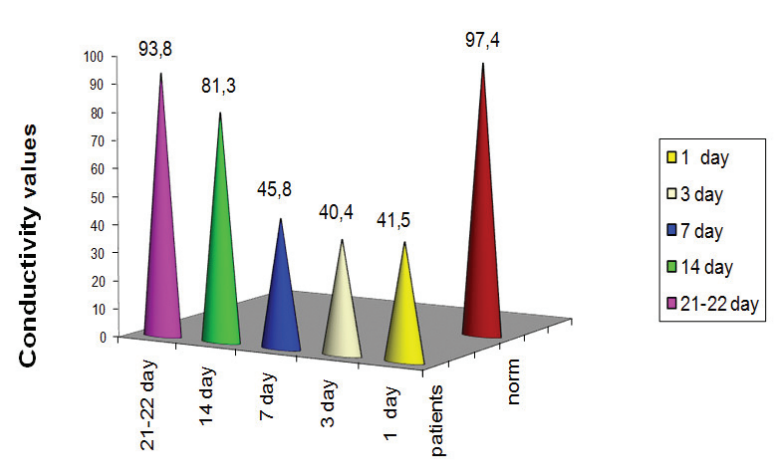

FIGURE 2. Conductivity values of the marginal branch of the facial nerve after parotidectomy in patients with nerve stretching in the dynamics of treatment.

On the next day after the parotidectomy was performed (Fig 3), the average arithmetic index of the resistance of the marginal branch of the facial nerve was $31.9 \pm 10.8$ units in 31 patients (at a norm of $11.3 \pm 0.6$ conventional units). This indicates a significant $(\mathrm{P}<0.001)$ decrease in this indicator. On the third day after the operation, there was a slight increase in the resistance rate to minus $27.8 \pm$ 10.1 units $(\mathrm{P}<0.001)$. On the 7 th day after the operative intervention, the resistance index of the marginal branch increased and amounted to minus $6.7 \pm 2.6$ units and still remained significantly lowered $(\mathrm{P}<0.001)$ compared to the indices of resistance of healthy people. On the 14th day of treatment, the index of resistance of the marginal branch of the facial nerve continued to increase and was already $5.8 \pm 0.5$ units, but still remained significantly lower $(\mathrm{P}<0.01)$ than healthy people (norm). On days 21 22 the resistance index of the marginal branch of the facial nerve was $10.2 \pm 0.4$ conventional units in these subjects and already reliably $(\mathrm{P}>0.05)$ did not differ from the index of resistance of healthy people (Fig 3).

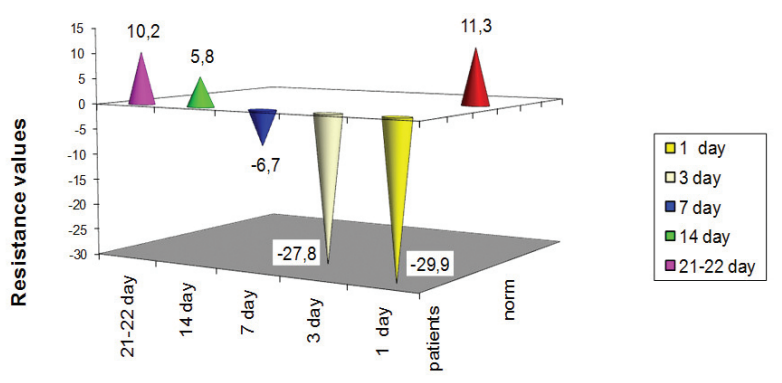

FIGURE 3. Values of resistance of the marginal branch of the facial nerve after parotidectomy in patients with nerve stretching in the dynamics of the treatment. 
The next day after the operation (Fig 4), in 31 patients the arithmetic value of the tone of the marginal branch of the facial nerve was $2.72 \pm 0.04$ units (at the norm of $2.18 \pm 0.01$ units $)$. This indicates a significant $(\mathrm{P}<0.001)$ increase in the tone of the corresponding branch of the facial nerve. On the 3 rd day after the operation, a decrease in the tone index was observed in comparison with the previous examination period to $2.52 \pm 0.04$ units $(\mathrm{P}<$ $0.001)$. On the 7 th day after the operation, the index of the tone of the marginal branch was $2.36 \pm 0.01$ units and still remained significantly elevated $(\mathrm{P}<0.001)$ compared to the index of the edge branch of the facial nerve of healthy people (norm). On the 14th day of the treatment, the index of the edge branch normalized and was $2.24 \pm 0.01$ units $(\mathrm{P}<0.001)$. On the 21-22th day the index of the tone of the marginal branch of the facial nerve in these subjects was $2.19 \pm 0.02$ units and already reliably $(\mathrm{P}>0.05)$ did not differ from the index of the tone of the marginal branch of the facial nerve of healthy people (Fig 4).

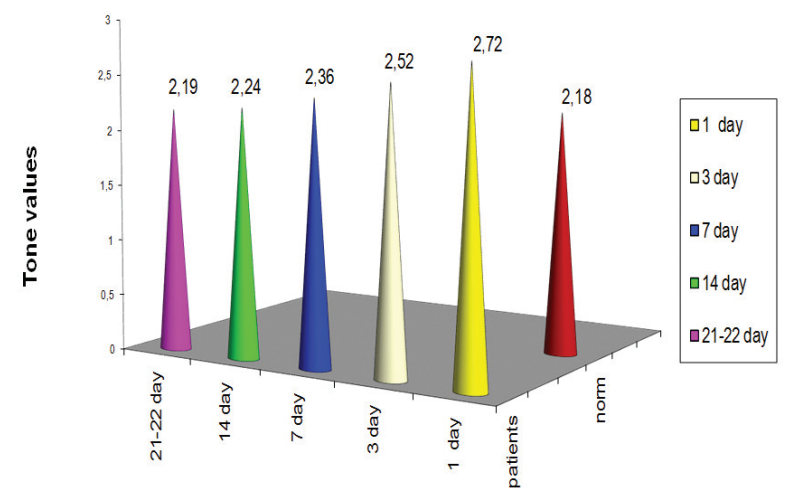

FIGURE 4. The indices of the tone of the marginal branch of the facial nerve after parotidectomy in patients with nerve stretching in the dynamics of the treatment.

The next day after the operation (Fig 5) in 31 subjects, the arithmetic value of the conductivity of the buccal branches of the facial nerve was $40.1 \pm 1.1$ units (at a rate of $96.5 \pm 1.8$ conventional units). This indicates a significant $(\mathrm{P}<0.001)$ decrease of this indicator. On the $3 \mathrm{rd}$ day after parotidectomy, the value of this indicator was kept at a low level and it was equal to $42.1 \pm 1.1$ conventional units ( $P$ $<0.001)$. On the 7 th day after the operation, the index of conductivity of the buccal branches remained practically at the same level and amounted to $47.7 \pm 1.2$ units, i.e. also remained significantly lower $(\mathrm{P}<0.001)$ compared to healthy people. On the 14th day of the treatment, the index of conductivity of the buccal branches increased and was $76.7 \pm 1.5$ conventional units and still was significantly lower $(\mathrm{P}<0.001)$ compared with healthy people. On the 21-22th day, the index of conductivity of the buccal branches of the facial nerve in the same subjects was 93.2 \pm 1.1 units and already reliably $(\mathrm{P}>0.05)$ did not differ from the group of healthy people (Fig 5).

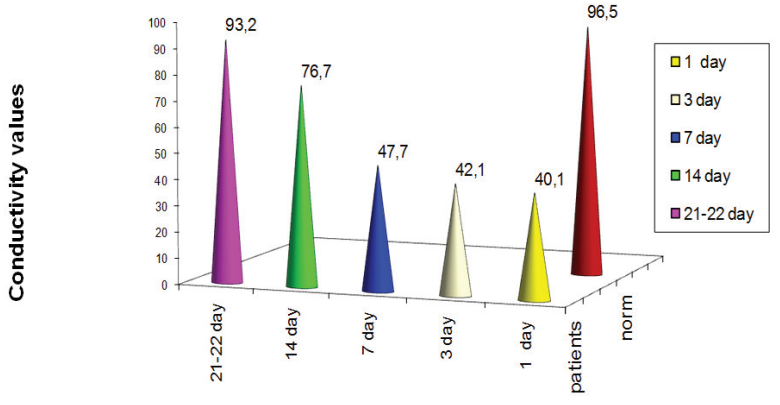

FIGURE 5. Conductivity values of the buccal branches of the facial nerve in patients with nerve stretching after parotidectomy in the dynamics of treatment.

The next day after the parotidectomy was performed (Fig 6), the average arithmetic index of resistance of the buccal branches of the facial nerve in 31 of the examined patient was minus $29.9 \pm 10.7$ units (At a norm of 11.2 \pm 0.6 standard units). This indicates a significant $(\mathrm{P}<$ $0.001)$ decrease in this indicator. On the 3rd day after the operation, the resistance index was maintained at the same level - minus $29.9 \pm 10.7$ units $(\mathrm{P}<0.001)$. On the 7 th day after the operative intervention, the index of resistance of the buccal branches increased and amounted to minus 4.8 \pm 1.8 units and still remained significantly lowered $(\mathrm{P}<$ $0.001)$ compared with the indices of resistance of healthy people. On the 14th day of the treatment, the index of resistance of the buccal branches continued to increase and was already $7.9 \pm 0.4$ units, but still remained significantly lower $(\mathrm{P}<0.01)$ than of healthy people. On days $21-22$, the index of resistance of the buccal branches of the facial nerve in the same subjects was $10.2 \pm 0.4$ conventional units and already reliably $(\mathrm{P}>0.05)$ did not differ from the index of resistance of healthy people (Fig 6).

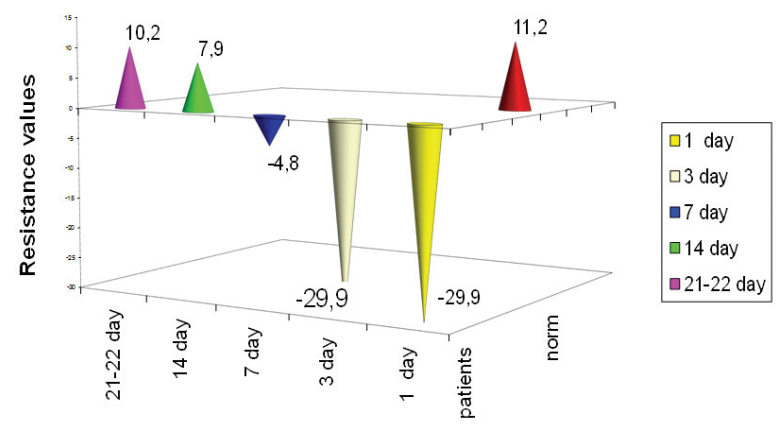

FIGURE 6. Indicators of resistance of the buccal branches of the facial nerve in patients with nerve stretching after parotidectomy in the dynamics of the treatment.

On the next day after the operation (Fig 7), the average arithmetic index of tone of the cheek branches of the facial nerve in 31 examined patients was $2.58 \pm 0.04$ units (at a norm of $2.19 \pm 0.01$ units). This indicates a significant (P 
$<0.001)$ increase in the tone index of the buccal branches of the facial nerve. On the third day after the operation, a significant increase in the index of tone of the cheek branches was maintained $-2.41 \pm 0.01$ units $(\mathrm{P}<0.001)$. On the 7 th day after the operation, the index of the tone of the buccal branches was $2.36 \pm 0.01$ units and was significantly elevated $(\mathrm{p}<0.001)$ compared with the index of the tone of the buccal branches of the facial nerve of healthy people (control group). On the 14th day of the treatment, the index of the tone of the buccal branches remained elevated and was $2.29 \pm 0.01$ units $(\mathrm{P}<0.01)$. On the 21-22th day the index of the tone of the buccal branches of the facial nerve in these subjects was $2.19 \pm$ 0.02 units and reliably $(\mathrm{P}>0.05)$ did not differ from the index of the tone of the buccal branches of the facial nerve of healthy people (Fig 7).

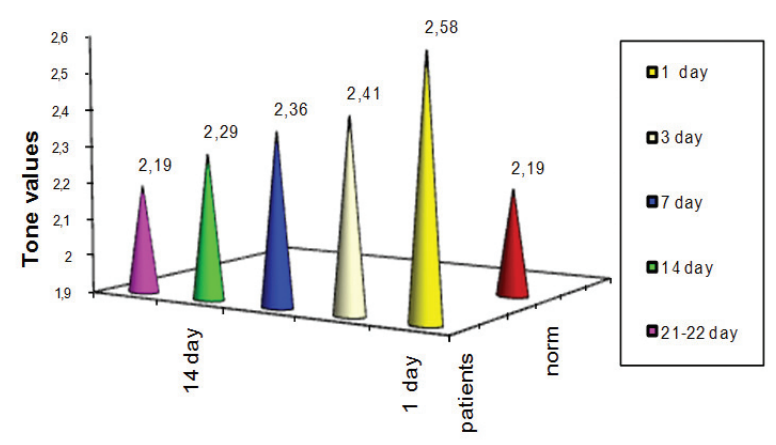

FIGURE 7. The parameters of the tone of the buccal branches of the facial nerve in patients with nerve stretching after parotidectomy in the dynamics of the treatment.

The next day after the operation (Fig 8), the average arithmetic index of conductivity of the zygomatic branches of the facial nerve in 31 of the examined patient was $40.7 \pm 1.1$ standard units (with a norm of $97.6 \pm 1.9$ units). This indicates a significant $(\mathrm{P}<0.001)$ decrease in this indicator. On the 3rd day after parotidectomy, the value of this indicator remained at the same level and it was equal to $41.7 \pm 1.0$ conventional units $(\mathrm{P}<0.001)$. On the 7 th day after the operation, the conductivity index of the zygomatic branches increased insignificantly and amounted to $44.6 \pm 1.2$ units, i.e. remained significantly lower $(\mathrm{P}<0.001)$ compared to healthy people (control group). On the 14th day of the treatment, the index of conductivity of the zygomatic branches significantly increased in comparison with the previous examination period and was $76.2 \pm 1.5$ conventional units and still was significantly lower $(\mathrm{P}<0.001)$ compared with healthy people. On days 21-22 the conductivity index of the zygomatic branches of the facial nerve in these subjects was $94.4 \pm 1.3$ units and already reliably $(\mathrm{P}>0.05)$ did not differ from the group of healthy people (Fig 8).

The next day after the parotidectomy performed (Fig 9), the average arithmetic index of resistance of the zygomatic branches of the facial nerve in 31 patients

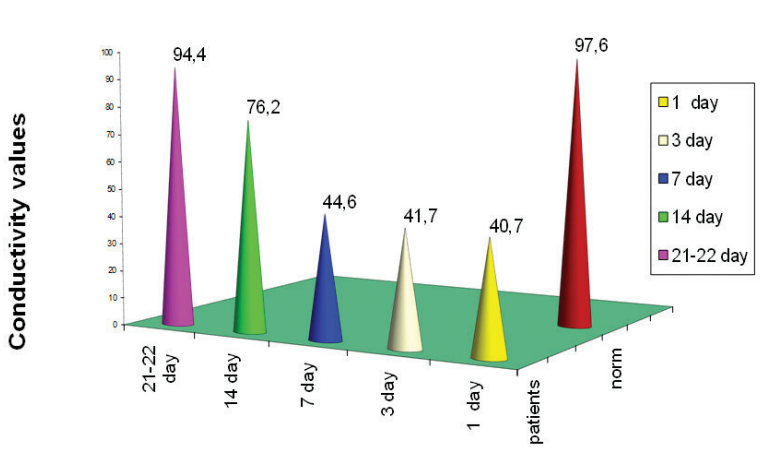

FIGURE 8. Conductivity indicators of the zygomatic branches of the facial nerve in patients with nerve stretching after parotidectomy in the dynamics of treatment.

surveyed was minus $29.7 \pm 10.7$ units (at the norm of $12.4 \pm 0.6$ standard units). This indicates a significant $(\mathrm{P}<$ 0.001 ) decrease in the resistance rate. On the 3rd day after the operation, the indices of the zygomatic branches of the facial nerve practically remained at the same level and amounted to minus $30.0 \pm 10.8$ units $(\mathrm{P}<0.001)$. On the 7 th day after the operation, the index of resistance of the zygomatic branch increased to minus $5.9 \pm 2.3$ units and remained reliably reduced $(\mathrm{P}<0.001)$ compared with the indices of resistance of healthy people (control group). On the 14th day of treatment, the index of zygomatic branch resistance continued to increase and was $5.5 \pm 0.5$ units, but still remained significantly lower $(\mathrm{P}<0.01)$ compared to healthy people. On 21-22 days after the operation, the resistance index of the buccal branches of the facial nerve in these subjects was $10.7 \pm 0.4$ conventional units and reliably $(\mathrm{P}>0.05)$ did not differ from the index of resistance of healthy people (Fig 9).

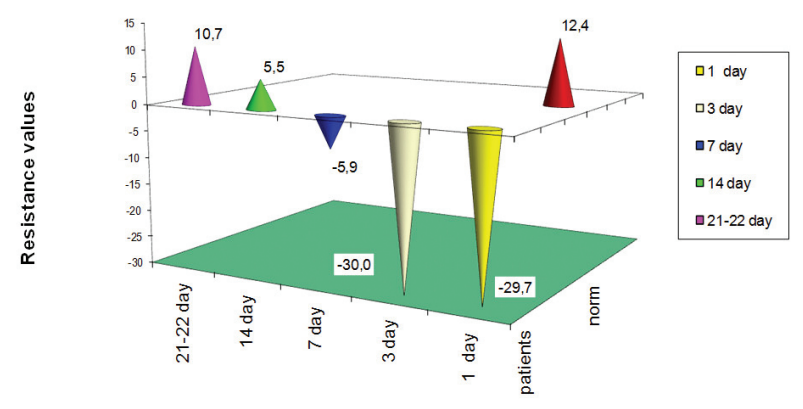

FIGURE 9. Indicators of the resistance of the zygomatic branches of the facial nerve in patients with nerve stretching after the performed parotidectomy in the dynamics of treatment.

The next day after the operation (Fig 10), the average arithmetic index of tone of the zygomatic branches of the facial nerve in 31 of the examined patient was $2.64 \pm$ 0.01 units (at a rate of $2.19 \pm 0.01$ units), which indicated a significant $(P<0.001)$ increase in the tone of the zygomatic branches of the facial nerve. On the third day after the operation, the increase in the index of tone of the 
zygomatic branches was maintained $-2.41 \pm 0.01$ units $(\mathrm{P}$ $<0.001)$. On the 7 th day after the operation, the index of tone of the zygomatic branches was $2.36 \pm 0.01$ units and remained significantly elevated $(\mathrm{P}<0.001)$ compared with the index of the zygomatic branches of the facial nerve of healthy people. On the 14th day of treatment, the index of tone of the zygomatic branches remained elevated and was $2.29 \pm 0.01$ units $(\mathrm{P}<0.01)$. On the $21-22$ th day the index of tone of the zygomatic branches of the facial nerve in these subjects was $2.19 \pm 0.02$ conventional units and reliably $(\mathrm{P}>0.05)$ did not differ from the tone index of the zygomatic branches of the facial nerve of healthy people (Fig 10).

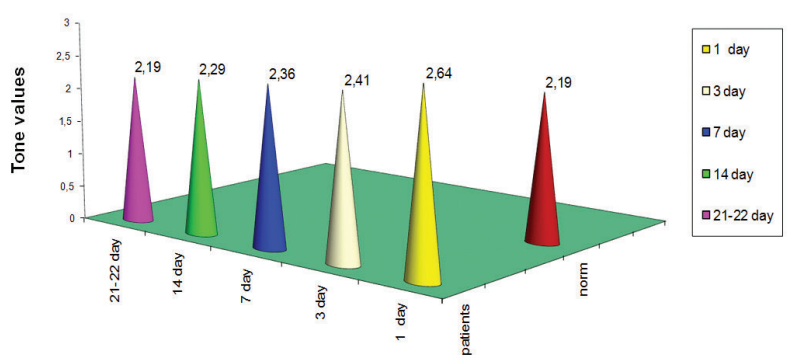

FIGURE 10. Values of the tone of the zygomatic branches of the facial nerve in patients with nerve stretching after parotidectomy in the dynamics of the treatment.

In cases after surgery on large salivary glands with stretching (during surgery) of the facial nerve, we found a regularity in the changes in the conductivity, resistance and tone of soft tissues innervated by this nerve in the postoperative period. The next day after the operative intervention, there was a significant decrease in the values of the conductivity and resistance of the nerve. These indicators reached their maximum deviations during the first 3 days after the operation. The parameters of the tone after the operation were increased, and reached their maximum values for the next day after the operation. With a favorable postoperative course (without the presence of hematomas in the area of postoperative wounds and extensive hemorrhages), changes in the conductivity, resistance and tone of the facial nerve in the direction of their normalization were observed on the 7-14th day after the operation. Positive changes in these indicators appeared 7-10 days earlier than the first clinical signs of neuropathy disappeared. Normalization of electrophysiological indices of soft tissues innervated by the facial nerve and complete disappearance of the clinical symptoms of the facial nerve neuropathy in patients treated with the hardware-software complex "DIN-1" occurred on the 21-22 day after the operation. If the postoperative period is unfavorable, i.e. in cases with hematomas and extensive hemorrhages in the area of the postoperative wound, the normalization of the previously mentioned parameters occurred slowly, approximately 7-10 days longer (the wound after these operations is always under the pressure gauze circular bandage that is retained without its replacement about 6-7 days, which makes it difficult to inspect the postoperative field).

Thus, the definition of static and dynamic electrophysiological parameters (conduction, resistance, tone) of soft tissue sites that are innervated by the facial nerve is a reliable prognostic test indicating a favorable or unfavorable course of the postoperative period in these cases and the effectiveness of the rehabilitative treatment of facial nerve neuropathies caused by stretching the nerve.

Based on the performed examinations of patients after surgical interventions (removal of tumors and tumor-like formations) on the parotid and submandibular glands, we found that in the postoperative period, the neuropathy of the facial nerve can occur, the cause of which is nerve stretching during an operative intervention. By measuring the static and dynamic electrophysiological parameters (conduction, resistance, tone) of soft tissue sites that are innervated by the facial nerve, we have proved the presence of postoperative neuropathy of the facial nerve caused by its stretching during parotidectomy. Neuropathy caused by stretching of the facial nerve, with a favorable course of the postoperative period and traditional medical treatment, is cured no earlier than 3 months after the operation.

The use of the hardware-software complex "DIN-1" for the diagnosis of this pathology and its treatment allows not only to reveal and prove the fact of the existence of the facial nerve neuropathy caused by its stretching during the operative intervention, but also to shorten the time for rehabilitation of such patients 4 times. Control of duration of treatment of neuropathies of the facial nerve was 36 patients operated on the parotid and submandibular glands with extension (during the operation) of the facial nerve without treatment with the hardware-software complex "DIN-1".

\section{Conclusion}

It was found out that in cases after surgical interventions on the parotid and submandibular glands, during which there is an extension of the branches of the facial nerve during the operation, the neuropathy of the nerve can be observed in the postoperative period [10-17]. The fact of the existence of the neuropathy of the facial nerve, caused by its stretching, is proved in patients after surgical interventions. Neuropathy caused by stretching during the operation of the facial nerve, with a favorable course of the postoperative period, with traditional treatment is cured no earlier than within 3 months after the surgery. Using the hardware-software complex "DIN-1" in the complex treatment of these patients allowed us to shorten the terms of their rehabilitation by 4 times.

\section{Funding}

None. 


\section{Conflict of Interests}

The authors declare no conflict of interest.

\section{Role of Author and Co-authors}

Oleksii O. Tymofieiev (concept of the paper and editing). Anna I. Kryvosheieva (material collection and writing). Beka Beridze (material collection).

\section{Ethical Approval}

Approval was obtained from the Medical Ethics Committee of the Shupyk National Medical Academy of Postgraduate Education, Kyiv, Ukraine.

\section{Patient Consent}

Not required.

\section{References}

1. Tymofieiev OO. Diseases of the salivary glands [Ukrainian]. 1st ed. Lviv: VNTL-Klasyka; 2007.

2. Tymofieiev OO. Maxillofacial surgery [Russian]. 2nd ed. Kyiv: Medytsyna; 2015.

3. Tymofieiev OO. Manual of maxillofacial and oral surgery [Russian]. 5th ed. Kyiv: Chervona Ruta-Turs; 2012.

4. House JW, Brackmann DE. Facial nerve grading system. Otolaryngol Head Neck Surg 1985.93: 146-7.

5. Danner CJ. Facial nerve paralysis. Otolaryngol Clin North Am 2008; 41(3):619-32. http://dx.doi. org/10.1016/j.otc.2008.01.008.

6. Kang TS, Vrabec JT, Giddings N, Terris DJ. Facial nerve grading systems (1985-2002): beyond the HouseBrackmann scale. Otol Neurotol 2002;23(5):767-71. http://dx.doi.org/10.1097/00129492-200209000-00026.

7. Vrabec JT, Backous DD, Djalilian HR, et al. Facial nerve grading system 2.0. Otolaryngol Head Neck Surg 2009.140(4):445-50. http://dx.doi.org/10.1016/j. otohns.2008.12.031
8. Tymofieiev OO, Vesova OP, Vesova AI, Portnichenko VI, Kolyada YM. Method of determining of the facial nerve injury [Russian]. Shupyk National Medical Academy of Postgraduate Education. Patent for Utility Model bull \#21. 6789. 2008-11-10.

9. Tymofieiev OO, Ushko NO, Vesova OP, Yarifa MO. Diagnostics of severity of the trigeminal nerve injuries during jaws surgeries. J Diagn Treat Oral Maxillofac Pathol 2017;1:32-9. htt://dx.doi.org/10.23999/j. dtomp.2017.1.4.

10. Fareed M, Mowaphy K, Abdallah H, Mostafa M. Temporary facial nerve paralysis after parotidectomy: the mansoura experience, a prospective study. Egypt J Surg 2014;33:117-24. htt://dx.doi.org/10.4103/11101121.131677.

11. Marchese-Ragona R, De Filippis C, Marioni G, Staffieri A. Treatment of complications of parotid gland surgery. Acta Otorhinolaryngologica Italica. 2005;25(3):174-8.

12. Bittar RF, Ferraro HP, Ribas MH, Lehn CN. Facial paralysis after superficial parotidectomy: analysis of possible predictors of this complication. Braz J Otorhinolaryngol 2016;82(4):447-51. https://doi. org/10.1016/j.bjorl.2015.08.024.

13. Dulguerov P, Marchal F, Lehmann W. Postparotidectomy facial nerve paralysis: possible etiologic factors and results with routine facial nerve monitoring. Laryngoscope 1999;109:754-62. https:// doi.org/10.1097/00005537-199905000-00014.

14. Reilly J, Myssiorek D. Facial nerve stimulation and postparotidectomy facial paresis. Otolaryngol Head Neck Surg 2003;128:530-3. https://doi.org/10.1016/ S0194-59980300089-5.

15. Blevins NH, Jackler RK, Kaplan MJ, Boles R. Facial paralysis due to benign parotid tumors. Arch Otolaryngol Head Neck Surg 1992;118(4):427-30.

16. Nader ME, Bell D., Sturgis EM, Ginsberg LE, Gidley PW. Facial nerve paralysis due to a pleomorphic adenoma with the imaging characteristics of a facial nerve schwannoma. J Neurol Surg Rep 2014;75:e84e88. http://dx.doi.org/ 10.1055/s-0034-1368149.

17. Varadharajan K, Beegun I, Daly N. Use of steroids for facial nerve paralysis after parotidectomy: A systematic review. World J Clin Cases 2015;3(2):180-5. http:// dx.doi.org/10.12998/wjcc.v3.i2.180. 


\section{Нейропатії лицевого нерва, що викликані його розтяжінням}

Олексій Олександрович Тимофєєв', Анна Ігорівна Кривошеєва², Бека Берідзе

Заведувач кафедри щелепно-лицевої хірурәії Інституту стоматології Національної медичної ака-

2 Асистент кафедри хірураіної стоматології та щелепно-пицевої хіруреії ПВНЗ «Київьький медичний університет», к. мед. н.

Аспірант кафедри щелепно-лицевої хірураії Інституту стоматології Національної медичної академії післядипломної освіти імені П. Л. Шупика.

\section{П Р О С Т А Т Ю}

\section{P E 3 Ю M E}

Історія рукопису:

Отриманий: 10 квітня 2017 року Прийнятий: 15 квітня 2017 року Онлайн з: 30 червня 2017 року

Ключові слова:

Лицевий нерв

Електрофізіологічні показники

Розтяжіння нерва

Привушна залоза

Піднижньощелепна залоза

Параліч лицевого нерва

Невропатія лицевого нерва
Мета. Вивчити динаміку змін електрофізіологічних показників лицевого нерва у хворих після проведення оперативніх втручань на великих слинних залозах і визначити можливість застосування електростимуляції нерва на апаратурно-програмному комплексі «ДІН-1» для лікування нейропатії, викликаної його розтяжінням.

Методи. Проведено обстеження 31 хворого після оперативних втручань на великих слинних залозах.

Результати. На підставі проведених обстежень хворих після проведення оперативних втручань було встановлено, що в післяопераційному періоді може спостерігатися нейропатія лицевого нерва, причиною якої $€$ не його травма, а розтяжіння даного нерва. Клінічне поліпшення i ліквідація симптоматики корелювали з нормалізацією електрофізіологічних показників стану уражених гілок лицевого нерва. Висновки. За рахунок застосування апаратурно-програмного комплексу «ДІН-1» для діагностики та лікування нейропатії лицевого нерва, що викликана його розтяжінням, нам вдалося не тільки виявити і довести факт існування даного захворювання, але і скоротити терміни реабілітації хворих в 4 рази.

\section{Нейропатии лицевого нерва вызванные его растяжением}

Алексей Александрович Тимофеев ${ }^{1}$, Анна Игоревна Кривошеева², Бека Беридзе 3

Заведующий кафедрой челюстно-лицевой хирургии Института стоматологии Национальной ${ }^{2}$ Ассистент каредеры хирургической стоматолологии и челюстно-личиевой хирургии Пвуз «Киев${ }_{3}$ ский медицинский университет», к. мед. н..
Аспирант кафредры челюстно-лицевой хирургии Института стоматологии Национальной медицинской академии последипломного образования имени П. Л. Шупика.

\section{O C TATbE}

\section{P E 3 Ю M E}

История рукописи:

Получена: 10 апреля 2017 года Принята: 15 апреля 2017 года Онлайн с: 30 июня 2017 года

Ключевые слова:

Лицевой нерв

Электрофизиологические показатели

Растяжение нерва

Околоушная железа

Поднижнечелюстная железа

Большие слюнные железы.

Паралич лицевого нерва

Невропатия лицевого нерва
Цель. Изучить динамику изменений электрофизиологических показателей лицевого нерва у больных после проведения оперативных вмешательств на околоушной и поднижнечелюстной железах, а также определить возможность применения электростимуляции нерва на аппаратурно-программном комплексе «ДИН-1» для лечения нейропатии, вызванной его растяжением.

Методы. Проведено обследование 31 пациента после оперативных вмешательств на околоушной и поднижнечелюстной железах.

Результаты. На основании проведенных обследований больных после проведения паротидэктомий и экстирпаций поднижнечелюстных желез было установлено, что в послеоперационном периоде у них может наблюдаться нейропатия лицевого нерва, причиной которой является растяжение данного нерва. Клиническое улучшение и ликвидация симптоматики коррелировали с нормализацией электрофизиологических показателей состояния пораженных ветвей лицевого нерва.

Выводы. За счет применения аппаратурно-программного комплекса «ДИН-1» для диагностики и лечения нейропатии лицевого нерва, вызванной его растяжением, нам удалось не только выявить и доказать факт существования данного заболевания, но и сократить сроки реабилитации больных в 4 раза. 